\author{
移民大国ロシアの軌跡 \\ 一中国と中央アジアからの労働移動に着目して— \\ 堀 江 典 生 \\ (富山大学極東地域研究センター教授)

\section{Tackling Migration Problems: Chinese and Central Asian Workers in Russia} \\ HORIE, Norio \\ Professor, Center for Far Eastern Studies, University of Toyama
}

\begin{abstract}
This paper examines how Russia has addressed a series of migration issues since the collapse of the Soviet Union. To follow the history of Russia's migration issues, we examine legislative and institutional changes, and the academic trends of Chinese migration issues in Russia, and analyze the labor market structure where Central Asian migrant workers are embedded. Finally we examine how to define the problems faced by foreign workers in the labor market in a migration study of Russia.

The problems faced by the former Soviet countries after the collapse of the Soviet Union included how each country would manage the newly established borders and how they would control the human and commodity flows through them. In the early 1990s, Russia originally had to tackle how to receive ethnic Russians living in the former Soviet Union, how to resettle them, and how to control their increased flow. The revised law on forced migration in 1995 decreased the number of forced migrants from the former Soviet Union to Russia, and in turn a massive flow of Chinese migrants to Russia, especially to the Russian Far East, became the center of public attention. The Russian public and government considered the increasing numbers of Chinese migrant workers a threat to Russia and often dubbed such immigration the "yellow peril." However, recent academic research on Chinese migration studies in Russia tends to draw a clear line against such alarmist discourse and to explore the realistic features of Chinese migrants living and working in Russia. Such research showed that most Chinese migrant workers are traders and businessmen temporarily staying in Russia and are actively exploring business opportunities and creating employment. Chinese migrant workers are indispensable for the Russian Far East where the labor shortage is critical. But in general, Chinese migrant workers find jobs, not due to the traditional demand of Russia's labor market, but due to the demand created by Chinese businesses.
\end{abstract}

Keywords: Migration, Migrant worker, Russia, China, Central Asia 
The recent majority of foreign workers are from Central Asia. They are allowed to cross Russia's border without visas and to look for jobs without visas or work permits. Central Asian workers living in Russia are embedded in the Russian labor market and occupy unqualified and low-paid jobs at the bottom of the market, filling jobs Russians do not want. Central Asian workers are employed with the traditional demand that Russia's society always requires. Russia cannot maintain her economy and daily life without Central Asian workers. The Russian government, however, still fails to establish good governance to allow them to work legally, doesn't protect their human and labor rights, and doesn't ease the vulnerability they face as foreign workers. Migrant workers face much trouble in their daily lives and bureaucratic barriers to obtain legal status to stay and work in Russia. Without protecting their human and labor rights, the establishment of a common labor market in Eurasia, which is often mentioned in Russia, remains far from realization. Therefore we must scrutinize the real features of foreign workers in Russia's labor market and tackle the problems faced by foreign workers in Russia.

\section{1 移民大国ロシア}

ロシアは，広大な領土をもち，多くの国々と陸上で国境を接する国である。実に，14 カ国 と国境を接し，441 カ所で出入国管理や税関業務など国境業務を行っているという(1)。ソ連崩 壊といら激動の中, 国境管理・入国管理は後手に回り, ロシアの 90 年代は, 新生国家の国境 管理と移民管理の試行錯誤の 10 年であったが，陸上国境をもつ国の外国人受入は，我が国の ように海上国境しかもたない国にとって想定しがたい問題が山積していた。

プーチン大統領就任から，ロシアは国境管理・移民管理の向上に努力を重ねてきた。2002 年に連邦法 No. $115 「$ 「シア連邦に打ける外国人の法的地位」（以後，「外国人地位法」と略称） が制定され，ようやく近代的な出入国管理・移民政策の枠組みが整った。とはいえ，この外国 人地位法は移民政策および外国人労働者管理に関わる重要なコンセプトを提示しているもの の，その具体的な運用や規定は数多くの大統領令，省庁令，政府決定等によって示されている ため，外国人にとってあまりに複雑だった。2006年に一連の移民関連法改正が行われ，2007 年 1 月からのそれらの諸法の施行により, ロシアは 90 年代から始まった出入国管理・移民政 策の試行錯誤に一定の結論を導き出したようである。

2010 年移民在留数でいえば，ロシアは米国に次ぐ世界第二位の移民大国なのである。ロシ アは，世界でも有数の外国人労働者受入国であり，日本のように高度な人材だけを正規に受け 入れているだけではなく，いわゆる出稼ぎ単純労働者も正規に受け入れている国である。旧り 連諸国からの外国人が約半数, それ以外の国々からは, 中国を筆頭に, トルコ, ベトナム, 北朝 鮮，旧ユーゴスラビアなど，多様な国からの 243 万人の正規外国人労働者を受け入れている (2008 年現在)。おまけに控えめな評価としても 700 万人から 800 万人がロシアで不法に働いて いるというのだから（Laruelle, 2007, p. 104）(2)，ロシアは世界屈指の労働移民大国なのである。

(1) Журнал Таможня, № 1-2, 2006, c. 7。複合国境検問施設は，そのうち 317 箇所という。

(2) ロシアに扔ける不法移民数に関する報道では, 最も控えめな報道は連邦保安庁国境局の 300 万人, 最 も多い推計は内務省報道で 1 千万人というょうに，あまりに大きな違いを示している（Рыбаковский, 2009, c. 7)。 
本稿の目的は，ロシアが移民大国化していく軌跡を，制度変遷と研究潮流を追うことで描く ことである。本稿では，主に中国拈よび中央アジア諸国からの労働移民に着目している。90 年代に打ける本格的な移民問題は, 帰還移民問題を除き, 中国人労働移民にまつわる議論が中 心であったこと, そして現在の労働移民の大部分が中央アジアからの出稼ぎ労働者によって占 められているといらことが，これら二つの移民の流れに着目する理由である。本稿では，ソ連 崩壊から現在に至るまでの移民関連法整備の変遷を概観するとともに， ロシアに拈ける中国人 移民問題の最近の研究潮流を追い，さらに中央アジアからの出稼ぎ労働者がぞのようにロシア の労働市場の底辺に構造的に組久込まれているかを論じ，ロシアに打ける「外国人労働者問 題」研究の位置づけを行いたい。

\section{2 ソ連崩壊からの移民問題と政策の変遷}

ソ連が崩壊し，旧ソ連諸国の国々が直面した問題は，新たに生まれた国境と従来のソ連の国 境をそれぞれの国がどのように監督し，国境を越える物流や人の移動をどのように管理できる かといら問題であった。1992 年にできたばかりの連邦移民局は，いまだ旧ソ連の法体系をな ぞりながら，旧ソ連諸国に残るロシア人の帰還問題に対応しなくてはならなかった。そして， この帰還移民問題が，特に，1991 年から 1996 年頃むでのロシアの移民政策の焦点であった。 1995 年末に改正された強制移動民法により, 強制移動民認定基準が㛜格化され, 以降強制移 動民認定数は減少していく。移民問題の焦点は, 帰還移民問題から不法移民問題へと次第に移 り変わる。ただし，「強制移動民」としての帰還移民問題はほとんど問題にならないレベルに まで認定者も減少したが, 在外ロシア人である「同胞 (соотечественники)」の保護と帰還奨 励の問題は残ったままである。在外ロシア系住民は, 関係国の政治問題になっているし, 特に ロシアにとって彼らの保護が安全保障上の重要課題になっている（湯浅, 2010, p. 38)。現在 でも 1800 万人はいると推定される在外ロシア人の帰還推奨は, 人口問題対策の重要な柱であ り，2006年の大統領令として施行された「在外同胞の自発的帰還促進国家プログラム」(3) の 枠組みで, 2008 年 7 月現在 (つまりプログラム施行一年半) で 3 千人がロシアに帰還している。 そのらち半数以上がカリーニングラード州へ再定住し, ロシア極東地域への再定住化も見られ ることから（Гребенюк, 2008, с. 38-39）, 政府の人口問題対策の特徵を色濃く反映している。

一方，不法移民問題への法的な対応が本格的に可能となるのは, 2001 年末の連邦移民局の 内務省への移管と 2002 年の「外国人地位法」の導入からである。当初，連邦移民局は，ぞの 省庁にも属さない政府直轄の局であった。しかし, その出自が旧ソ連時代の労働省副議長諮問 委員会であったため, 労働関連行政の色彩が強く, 地方の連邦移民局のスタッフも地方自治体 労働行政に携わっていた人々であった。1999年末に国内の民族問題の対応のために設立され た連邦・民族・移民政策省の傘下に入るが，2001 年末には同省が廃止され，連邦移民局は内 務省管轄となった。連邦移民局の内務省への移管は，帰還移民の安全を守ることから移民の脅 威から自国民を守ることを第一義とする安全保障政策にロシアの移民政策が転換したことを表 していた（堀江，2006）。

では，ロシアにとって移民に関わる脅威とは，どのようなものだったのだろらか。まず，第 一に挙げられるのは，中国人移民にまつわる脅威である。第二に，CIS 諸国からの移民にまつ

(3) このプログラムの実施期間は，2006 年から 2012 年までである。 
わる脅威である。このふたつの脅威の区別は重要である。簡単に説明したい。

中国人移民にまつわる脅威については，その脅威が現実的であったのかどらかについては， 疑問がある。もちろん, 中国人労働者拉よび非正規移民のロシア極東への流入が，90 年代初 めの安価で決して質が良かったとは言えない中国製品の流入と合わせて脅威とされ，中国の口 シア極東地域への経済的拡張を不安視する論調が門られたのは確かである。しかし，当時はま だ旧ソ連時代末期に, 長い中ソ対立の溶解からようやく労務輸出やビザなし観光が再開され, ソ連崩壊とともに国境管理がルーズになり，どれほどの中国人の入国・出国があったかを正確 に把握することはできなかった時代であった。

中露国境の入国管理強化と中国人移民へのビザ制度の導入により, 公式統計として中国人移 民数が把握できるようになったのは，ようやく 1994 年になってからである。ロシアは，中国 東北地方の熱気とは裏腹に, 中国からの物流や人の移動に対応する制度基盤の準備ができてい なかった。それゆえ, 1990 年代にロシア極東地域が, 中国人移民妿威論に沸いたのは, 人口 圧力の高い中国東北地方と国境をはさみ，不法な越境を受けていたからだとするのは，あまり に単純である。

たびたび誇張される中国人不法移民情報には今でも枚挙に遑がなかった。2005 年に報道さ れた中国人移民数では，内務省報道として 40 万人から 70 万人，各紙報道として 300 万人から 1200 万人，国民経済予測研究所は労働者だけでも 80 万人との評価がある。ただ，近年中国人 移民もしくは労働者が，ルールベースでロシアに入国・帰国する傾向にあることは 1990 年代 後半からの着実な傾向である。中国人移民が，ルールベースでロシアに入国・帰国する傾向に ある現在, 問題の所在は, ロシア極東地域の再開発が進まず, 市場経済化に伴う地域経済の斜 陽が放置され, 極度の人口減少・流出に悩みながら, その損失を補らために多くの他の地域が 受け入れているような旧ソ連諸国の移民労働者の受入もままならず, 中国打よび北朝鮮からの 移民労働者に依存せざるをえない極東ロシアの地政学的な立場から生まれる焦りである ${ }^{(4)}$ 。 根本的な問題が解決しないままでは, 常に脅威論が再燃する危険性もあることに留意する必要 がある(5)。

中国人移民艿威論は，確かに中国人の不法移民を問題にしていたが，それ以上に，ロシアの 文化的統一性への脅威や民族構成への悪影響などが語られたように，中国人そのものの越境と 隣国中国の台頭に脅威を感じていた感があった。他方，CIS 諸国からの移民にまつわる脅威で は, 民族構成や文化的統一性などについての脅威が喧伝されることはなく，「不法移民との戦 い」といらスローガンに象徴されるように，不法移民・非正規活動そのものに焦点があった。

CIS 諸国からの外国人労働者たちは, ビザ免除のため, ロシアに入国後自由に就労先を探す ことができる。2006 年まで CIS 諸国からの労働者にも課せられていた面倒な労働許可取得の 手続きのせいで，多くの CIS 諸国からの労働者が不法移民化した。2006 年 2 月 23 日にモスク ワのバウマンスキー市場で起こった屋根崩落事故で死亡した人々のほとんどが中央アジア・カ フカスからの移民労働者で占められていた。また，最近では，チェルキゾフスキー市場の閉鎖

(4) ロシア極東住民の安全保障上の中国人および中国に対する脅威の認識が, 無理解と敵意を累積的に生 みだすことについては, Alexseev（2006）を参照されたい。

(5) 2001 年時点ロシア極東地域での住民調査で中国を脅威であると答えた回答者は全体の三分の一強で あった。また，中国人のプレゼンス増大はロシア極東の脅威であると答えたロシア極東国境諸都市の 回答者数は，全体の 7 割弱にも及んだ（Мотрич, 2006, с. 154-155）。 
を象徵的事件として取り上げることができる。この市場は，イズマイロヴォ地区にあり，中国 人移民による商業センターと挷揄されていた。この市場が 2009 年 6 月 29 日に閉鎖された。衛 生・防災上の違反が直接的な理由ではあるものの, 同市場での密売と不法移民の一掃が目的で あった (6)。この市場の閉鎖により 2 万人の不法移民を含む 4 万 5 千人の移民たちが路頭に迷 らこととなったといらが，実はその多くは中央アジアからの外国人労働者であったことも見逃 せない。こうした事件により，ロシア社会がロシア市民と外国人労働者によって構成され， CIS 諸国からの移民労働なしには自国経済を運営できない状況にきていることも事実として受 け止められている。

2007 年からの労働移民関連の法改正は, CIS 諸国からの労働者に課せられる手続きを簡素 化し，彼らが合法的に㗢くことができるようにするものであったが，同時に，アルコール飲 料・薬剂・露天商などの小売業に拈いて外国人雇用が禁止されている。また，先進国企業の口 シア現地法人にとって面倒だった外国人スタッフ雇用は, 2010 年 5 月の「外国人地位法」改 正により高度人材については，労働許可割当の制限から外れた。高度人材の定義がこの改正で 明らかとなり，年収 200 万ルーブル（月収 16 万 6 千ルーブルで扮拈よそ 5.5 千ドル）以上となっ ている。敃执よそ先進国からの高度人材を対象として扣り，マネージャ一層といっても収入で は及ばない中国や近隣諸国からの高度人材を排除する形となっている。

\section{3 中国人労働移民論の現在}

では，ロシアにおいて中国人移民問題は現在どのように論じられているのだろらか。代表的 なロシアの中国人移民論の近年の研究動向を追らことにより, ロシアに抢ける中国人移民問題 研究の特徴を明らかにしよう。

近年のロシアにおける中国人移民研究は, 中国脅威論とは一線を画した冷静な研究が目立 つ。ロシア極東地域に括いて中国人移民問題が現実的な脅威でないこと, 中ロ国境地域の経済 交流と中国人労働力がロシア極東地域にとって好むと好まざるに関わりなく不可欠であること を 90 年代から一貫して主張し冷静に分析してきたのは， ウラジオストクにあるロシア科学ア カデミ一極東支部極東諸民族歴史・考古学・民族学研究所のビクトル・ラーリンである。1998 年に出版された『90年代前半の中国とロシア極東 : 地域関係の諸問題』では, 中国人不法移 民問題は, 中国政府の問題というょりもロシア政府の問題であると言い切っている（Ларин, 1998, c. 116)。

2006 年にラーリンが刊行した『目覚めた龍の影で : 20 世紀と 21 世紀の間の中ロ関係』では, さらに興味深い調査結果が示されている。ロシア極東地域住民の間では, 中国人不法移民と労 働移民に対しては否定的態度が優勢であるが，旅行者，ビジネスマン，商業者に対する態度は 肯定的態度が否定的態度を上回っている。また，ロシアとアジア太平洋地域諸国との関係に関 する住民評価では，現状以上に将来に対する中国との関係に米国や日本との関係以上に期待を 示している構図が示されている（Ларин, 2006, c. 284-285）。ロシア極東地域での経済発展に積 極的にアジアの外国人労働力を活用すべきとして, ウラジオストク経済サービス大学のベズル

(6) ロシアの社会調查機関のひとつであるレヴァダ・センターが行ったモスクワ市民へのアンケート調査 では，67\%がこの市場の閉鎖を支持し，53\% が不法移民のせいで， $47 \%$ が密売問題， $41 \%$ が衛生管 理問題で閉鎖されたと考えている（www.rosbalt.ru/2009/07/20/656488.html）。 
コフとゴルベンコヴァは「発展のための移民（受入)」を唱えている（Безруков и Горбенкова, 2006）。中国から労働力不足に敛むロシア極東やシベリアへの労務輸出は, 中ロ両国にとって 利益のあることであるとの積極的な評価もある（Гришанова, 2009, с. 69）。また，好むと好ま ざるに関わりなく, ロシア極東地域は, 中国東北地方や北朝鮮, ベトナムなどからの外国人労 働者を「効率的な労働資源」として活用せざるを得ない段階にきている（大津・アブデーエフ， 2010, pp. 156-157)。ロシア極東地域では, 中国人移民問題や中国脅威論が再燃しやすい地域 であることは確かであるが，現実的な選択として国境を通じた中口経済関係を肯定的にとら え，共存していく未来を住民自身が見据えているとする主張は，近年の大きな研究潮流のひと つであると考えられる。

一方, ロシアのマスコミや当局が繰り返し喧伝する中国人不法移民数の推定值に関しては懐 疑的ながらも, 中国人移民そのものよりも中国人移民達が行ら組織的経済活動に警戒すべきで あり，それは中国が国家戦略として行っているとの論陣を張ってきたのが，ロシアを代表する 中国専門家のゲリブラスである。ゲリブラスは, 移民コミュニティをディアスポラ, 共同体 (община)，同郷人組織（землячества）に区別し，中国人移民の分析視角として「同郷人組織」 を採用した（Гельбрас, 2004, c. 43-47)。ディアスポラ, 共同体, 同郷人組織は, ロシア語で はしばしば同義語として扱われてきただけに，ゲリブラスはこの3つの峻別により中国人移民 分析に新たな境地を見いだした。その同郷人組織が，「闇」ビジネスも含めロシアにおいて事 業拡大し, 資本蓄積を行っていることがロシアのためにならないとゲリブラスは憂慮する。そ れゆえ，中国人移民を受け入れることは，「きわめて厄介である」（ゲリブラス，2005，p. 260） としている。

上記のラーリンやゲリブラスなどの労作は，どれもロシアの中国人移民問題を冷静に分析 し，ロシアおよびロシア極東地域への影響を見定めょうとする点では共通している。ラーリン もゲリブラスもマスコミや多くの学術論文で繰り返し利用される根拠の明確でない不法移民数 の推計值やアネクドータルな現状分析に依存するのではなく, 独自のアンケート調査などを実 施して中国人移民問題に迫ろらとしている点で, 両極ではあるがロシアに拈ける移民研究の重 要な到達点である。

ごく最近では，モスクワにあるロシア科学アカデミー極東研究所のアレクサンドル・ラーリ ンにより, 帝政時代からソ連時代までの中国人移民の歴史を概観し, 現代ロシアにおける中国 人移民の現状を独自の社会学的調査を織り交ぜながら論じた『ロシアの中国人移民』が 2009 年に刊行されている。中国移民問題を歴史的に概観しつつ, 総括的に描き挙げている点, 現代 の中国人移民を主に定住移民ではなく短期滞在型の移民としながらも，中国人コミュニティを 通じてディアスポラ的活動を事実上行う「疑似ディアスポラ（квазидиаспора）」として描い ている点, 900 人の中国人を対象とし，これまでロシアで行われた中国人移民に対するアン ケート調査の規模としては最大級の本格的な社会学的調査を実施し, その成果を生かしている 点にこの研究書の特徵がある。特に, ロシアにおいて著名な世論調査機関「全ロシア世論調査

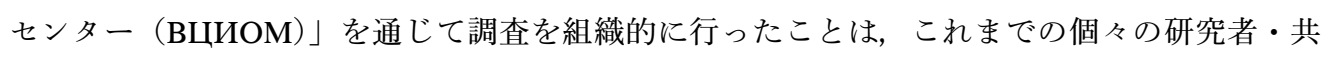
同研究者の努力によって行われてきた中国人移民モニタリングとの違いを際だたせている。多 くの社会学的調査の調査項目は, ゲリブラスの調査と重複するところが多いが，基本的には中 国人脅威論を諫める研究成果となっている。

モスクワ市在住者に限定した 120 人の中国人に対する調査を行ったリャザンッェフとヤンに 
よる『ロシアへの中国人移民：その傾向と帰結と規制方法』もまた興味深い研究成果である。 特に, 中国人移民が，コミュニティとしてロシア市民と交渉をもたず孤立し，ロシア社会に同 化したり市民交流を行ったりする意志がないとはいえ ${ }^{(7)}$, ロシア労働市場にしっかりと適応 し，移民として十分な収入を得ている点を指摘している。彼らの調査では，700-800 米ドルの 収入と答えた中国人移民が $30 \%$ に及び，それ以上の収入を得ている中国人移民 $36.7 \%$ を加え ると大半の中国人移民が「悪くない収入」を得ている，と評価している(Рязанцев и Ян, 2010, c. 78)。前述のアレクサンドル・ラーリンは中国人移民大多数の収入は「十分にささや か」であるとの控えめな評価（Ларин, 2009, c. 174）だが，多くの研究者は，リャザンッェフ とヤン同様に中国人移民が「十分な」収入を得ていると評価している。たとえば，ゲリブラス もウィッシュニックもロシアの中国人移民は十分に裕福であるとの評価を与えている（Гель6pac, 2001, c. 83 ; ウィッシュニック，2006, p. 94)。外国人労働市場に拈いてどのよらな階層 化が生じているのか， ロシアの労働市場の底辺で働いていると言われる中央アジアからの労働 移民たちと合わせて興味深いところである。

クラスノヤルスクのダッィシェンは, シベリアの中国人労働者需要が高いにもかかわらず中 国人労働者がシベリアにまでなかなか働きに来ない実情を描いている。たとえば，地方政府高 官までもが中国人労働者の不足に言及している。チタ市長は 2006 年にチタ市の建設計画には 中国人労働者を 4000 から 4500 人必要としているものの, 中国人労働者のために用意した労働 許可割当が完全に埋められることはなかったといら。また，クラスノヤルスクでは 2008 年に 中国人労働者のために 13357 人分の労働許可割当を用意したにもかかわらず，9935 人分しか 労働許可は発行されなかったという。中国人移民は, 振り子のように中ロを往来する卸売市場 や流通関係の仕事の関係者であるにもかかわらず，ロシアに拈いて単に労働者といらカテゴ リーで括られているために，ロシア側は中国からの労働移民の特徵を把握できないでいるとい う（Дацышен, 2009, c. 136)。地方, 特にシベリアやロシア極東地域に見られる安価な労働力 への需要とロシアでの商業活動にビジネスチャンをを見いだしてやってくる中国人移民との間 にミスマッチが生じているのである。ロシアにおける中国人労働者を労働移民として一括に取 り扱ってきた研究では，こうした地方の中国人労働移民の実情を捉えることはできない。中国 人労働力を経済部門ごとに評価することは難しく，今後の研究課題でもある。

さて, このように近年の中国人移民問題の諸論点をサーベイすると, 次のような共通理解を 見て取ることが出来るだろう。第一に, 中国人移民問題は, 脅威論に対しては冷静さを保ち, 現実的な中国人移民像を描こうとする研究がロシア全体で主流となっていること，第二に，そ らした研究により，ロシアで働く中国人は，自らのビジネスをロシアで積極的に展開し中国と ロシアを往来する短期ビジネス移民であること，第三に，それゆえ中国人労働移民はロシアの 労働力不足といら需要から生まれるのではなく, 中国人のロシア極東地域やシベリアでのビジ ネス展開に応じた需要から生まれるものであるということ, 第四に, そのビジネスは中国人以 外には閉鎖的であり, 中国人コミュニティがロシアのコミュニティやビジネスネットワークに らまく絡まない現実があるよらだ，といらことである。

(7) 中国人コミュニティおよびそのビジネスのロシア社会における孤立主義は, 様々な論者が論じてい る。たとえば，ディアトロフは，シベリア地域住民が独特に貿易を行う少数民族に敵意を見せる傾向 があることから，シベリアでの中国人移民問題の根っこを捉えようとしている（Dyatlov, 2000）。すで に紹介したゲリブラスの諸著作に拈ける中国人の同郷人組織論も，そらした中国人の孤立主義を表す ものである。 


\section{4 ロシア労働市場に組み込まれた中央アジア出稼ぎ労働者}

中ロを往来する中国人ビジネスマンや出稼ぎ労働者と異なり, ロシアの労働市場の需要を満 たすように出稼ぎにきているのは中央アジアからの労働移民達である。特に欧露部とシベリア の諸都市に拈ける中央アジア出稼ぎ労働者は, ロシアの労働市場の底辺を担ら役割を演じてい ると言える。2008 年現在ロシアに登録されている外国人労働者のらち，ウズベキスタン，タ

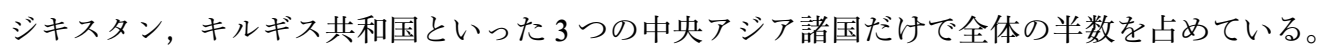
これだけロシアの労働市場は中央アジアからの出稼ぎ労働者に労働力を依存している証左であ る。一方, 中国からの労働力移動は, 全体の一割強（12\%）にすぎない。また，中国人労働者 が目立つ存在であるのはロシア極東地域や東シベリアで, CIS 諸国からの外国人労働者が目立 つのは主に欧露部であることから，特に労働市場で中国人と中央アジア人の競争が行われてい るわけではない。図 1 は，ビザ免除国からの外国人労働者と非ビザ免除国からの外国人労働者 がそれぞれ全外国人労働者のらち8 割以上を占める地域を示した地図である。ビザ免除国の中 心的な労働者を中央アジアからの外国人労働者, 非ビザ免許国からの外国人労働者の多数派が 中国人であることを考えれば，やはり中国人労働者が中ロ国境地域に集中し，中央アジアから の労働者があまりロシア極東地域にまで足を運ばない様子が見て取れるだろら。これは，ビザ 免除国外国人労働者が欧露部からシベリアまで, 非ビザ免許国外国人労働者である中国やその 他アジアからの外国人労働者がザバイカルまでといらよらに棲及分けを行っているとも言える し，労働許可制度抢よびその割当制度によりそのように統制されているとも言える。

中央アジアの出稼ぎ労働者と中国からの労働者では, 就労している分野も大きく異なる（図 2)。中国からの外国人労働者は, 小売・卸売などの商業分野および農林業の比重が高いのが特 徵である。それに比べて, 中央アジアからの外国人労働者は, 建築および「その他」で働く比 率が多い。「その他」は，公共サービスにかかわる労働，たとえば道路保全（雪割など）や公 共住宅清掃などを含み，これには多くの中央アジア移民達が関わっている。建築業で働く人々

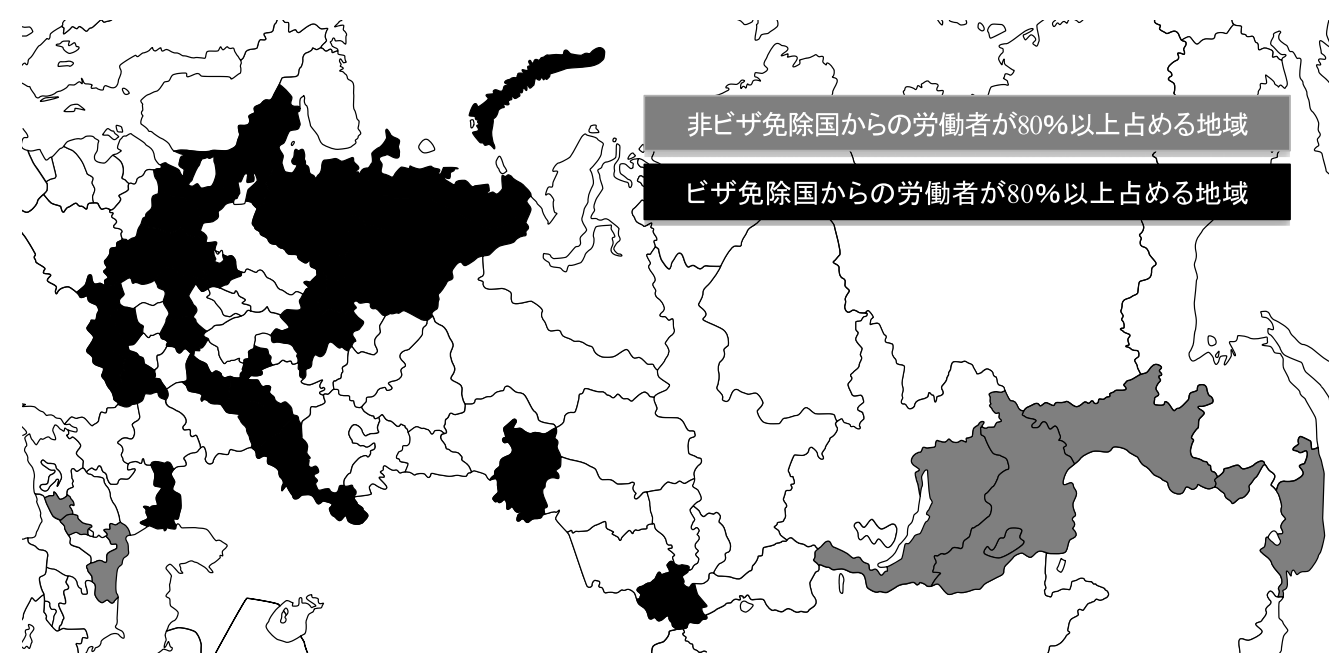

図 1 ビザ免除国・非ビザ免除国労働者分布 出所 : MOT (2009, c. 18-19) のデータより筆者作成 
は，中央アジアと中国を問わずに多いものの ${ }^{(8)}$, 中央アジアからの労働者は，日雇いなどを 含む柔軟な雇用が可能である一方，中国人労働者は入国前からの労働契約に基づくものが中心 となるために，中国資本が関わる建築や請負などに関わる建設労働が多いと推測される。

ロシアの外国人労働者の職業は, 2600 職種以上にのぼる。ロシアが労働者の管理・規制に 用いている全ロシア労働者職業・職員職務・賃金等級分類がそもそも極度に細分化された職業 分類であるからだが（堀江，2009，p. 86）, 職業階層を見るには便利である。この職業分類に は，それぞれの労働者職業に対応する賃率等級枠（1～8）が示されている。表 1 は最も需要 のある職業を示したものであるが ${ }^{(9)}$, 雑役夫は賃率等級最低の 1 から 2 , 棟瓦敷工は 2 から 6 , コンクリート工は 1 から 5 , 個人宅使用人 (家政婦) などに至っては昇級なしの最低賃金等級 1 というょうに，貢金等級低位の職業が需要の中心であることがわかる。また，ISCO-88 コー ドの大分類 9 （上一桁コード）は，初級の職業，いわば単純労働にあたり，大分類 6 から 9 ま でがブルーカラーに相当する。大分類 6 が農林水産関係熟練労働者, 大分類 7 が工業関連熟練 労働，大分類 8 がプラント・機械操作員および組立工などの労働者とすると，ロシアに拈ける 多くの外国人労働者に対する需要が工業関連の賃金等級の低い職業抢よび単純労働に集中して いることがわかる。

こうした労働市場の底辺を担う中央アジア出稼ぎ労働者が，本格的にロシアの労働市場に組 久込まれたのは今世紀に入ってからであり, 顕著に労働市場での存在感を増したのは 2007 年 以降である。ロシアに括いて旧ソ連地域からの労働移民問題が移民研究の中心課題になったの は，1990年代末から 2000年代初めであり，ちょらど旧ソ連諸国からの強制移動民 (エスニック・ ロシア人) 問題に一区切りついた頃であった（Рязанцев, 2007, c. 63)。この時期, 中央アジアか らの強制移動民が労働移民化することをロシアへの適応手段であるとする論文（Кириллова, 2003）がでているところなど, 関心の移り変わりを表している。

このように中央アジア出稼ぎ労働をロシアの労働市場の重要な構成要素であると見なす議論

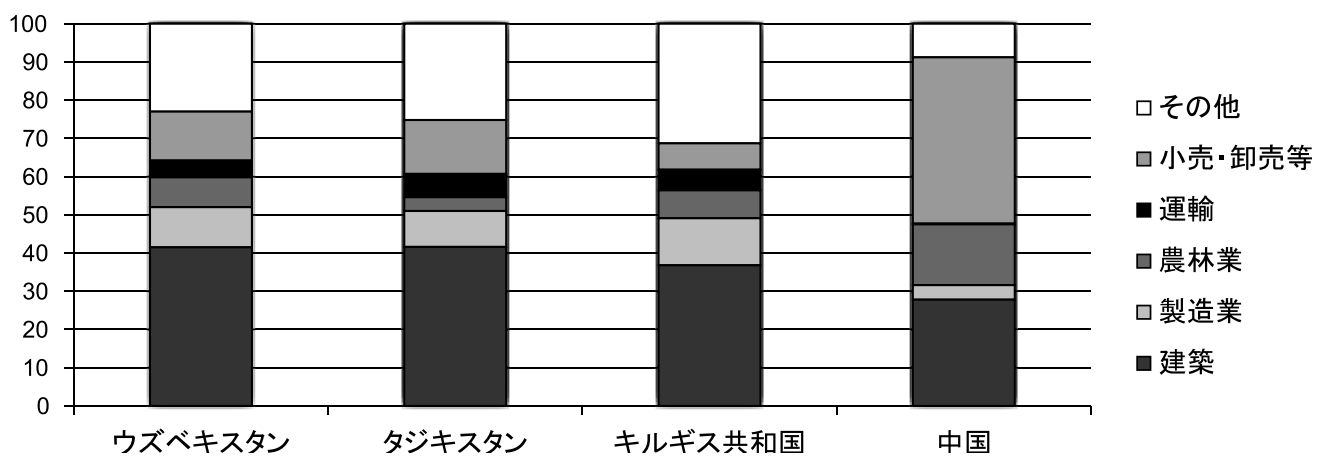

図 2 出身国別外国人労働者就労部門比率（2007 年） 出所: 内務省連邦移民局資料

(8) 建築部門就労者に占める外国人労働者の割合は $16.4 \%$, 他の部門に比べ（平均 3.4\%）突出している。 http://demoscope.ru/weekly/2010/0431/tema02.php 参照。

(9) 俸給職員にあたるホワイトカラーには, 顀金等級枠は与えられていないので，表 1 では事務・管理職 と明示した。また，2007 年以降に新たに職業分類に加えられた職業には労働者職業であっても賃金等 級枠は示されていない。N.A. と表示したのはそのためである。 
表 1 外国人労働者職業別分布（2008 年分雇用者申請）

\begin{tabular}{|l|c|c|c|}
\hline \multicolumn{1}{|c|}{ 職業名 } & 外国人労働者数 (千人) & ISCO-88 & 貢率等級 \\
\hline 雑役夫 & 168 & 9413 & $1-2$ \\
\hline 棟瓦敷工 & 104 & 7122 & $2-6$ \\
\hline 左官工 & 71 & 7133 & $2-6$ \\
\hline コンクリート工 & 59 & 7121 & $1-5$ \\
\hline 大工 & 50 & 7124 & $2-6$ \\
\hline 塗装工 & 48 & 7138 & $1-6$ \\
\hline 自動車運転手 & 39 & 8322 & $4-8$ \\
\hline 野菜栽培者 & 38 & 6111 & N.A \\
\hline 部品組立工 & 32 & 8246 & $2-5$ \\
\hline 荷役作業員 & 29 & 9413 & $1-2$ \\
\hline マネージャー & 27 & 1233 & 事務・管理職 \\
\hline 機械組立工 & 24 & 8221 & $2-3$ \\
\hline 外装工・タイル工 & 19 & 7121 & $2-5$ \\
\hline 技術, 商品販売の代理人 & 17 & 3415 & 事務・管理職 \\
\hline 電気ガス溶接工 & 12 & 7212 & $1-6$ \\
\hline 商業マネージャー & 12 & 1224 & 事務・管理職 \\
\hline コック & 10 & 5122 & $2-6$ \\
\hline 工場・事務所清掃員 & 12 & 9414 & $1-2$ \\
\hline 鉄筋コンクリート構造物組立工 & 92121 & $2-6$ \\
\hline 非食料品販売員 & 10 & N.A \\
\hline 道路保守労働者 & 9414 & $1-5$ \\
\hline 個人宅使用人 & 10 & & 1 \\
\hline & 12 & 5210 & \\
\hline
\end{tabular}

出所 : MOT (2009, c. 17-18）をもとに筆者作成。

が，ロシアにおいては高まっている。ロシアにおいて中央アジアからの出稼ぎ労働者は，ゼノ フォビアの対象であり忌避の対象であることはあっても, 脅威や敵意の対象とはなっていない （ディアトロフ，2010）。ザイオンチコフスカヤは, 中央アジアが人口減少に悩むロシアの重要 な移民供給源であり，リスクを伴うものの中央アジアからロシアへの移民流入は中央アジアと ロシアの経済発展にとって不可欠なプロセスであるとの認識を示している（ザィオンチコフス カヤ，2010）。行き着く構想としては，ユーラシアに扣ける統一的な移民制度と労働市場とい うことになる。イヴァハニュクは，ユーラシア経済共同体（ЕврАзЭС）を共通の移民制度の もとでまとまる母体となると考光ている（Ивахнюк, 2008, 2010） ${ }^{(10) 。 ~}$

(10) ロシア， ベラルーシ，カザフスタンは，域内での資金や労働力の移動を自由にする統一経済圏を 2012 年 1 月 1 日より始動させる予定であるが，それは将来的にはタジキスタンやキルギス共和国を含めた ユーラシア経済連合（Евразийский экономический союз）もしくはユーラシア同盟に発展する可能 性もある。 
ただし，ロシアの労働市場に組み込まれた外国人労働者，特に中央アジアからの外国人労働 者を取り巻く環境は厳しい。彼らが合法的に働ける環境をロシア政府も雇用者も生み出しては いない。テュルカノヴァによれば，合法的な外国人労働者と非合法な外国人労働者の間の所得 には大きな違いがないばかりか（合法的な外国人労働者平均月賃金 15,429 ルーブルに対し不 法就労外国人労働者の平均月賃金は 15,114 ルーブルと $5 \%$ ほどしか違わない)，合法的であろ らと非合法であろらと警察へ「罰金」を毎月 1400 ～ 1600 ルーブル支払っているといら。それ ゆえ, 彼女は「政府も経済制度も移民労働者が合法的に働くことを保障する枠組みを提供でき ていないし，移民労働者の経済的，法的，社会的リスクを軽減することもいまだにできていな いため，移民たちが合法化するインセンティブは今も少ない」(Тюрканова, 2010, 43）と論じ ている。

非合法的な地位に陥りやすい外国人労働者の現状については, 近年多くの研究者が質的調査 による接近を試みている(11)。これらの研究に共通して見られる傾向は, 外国人労働者が国境 や労働の現場，そして日常生活に抢ける社会的リスクを外国人労働者の声から明らかにしょう としていることである。低賃金労働を担う中央アジアからの外国人労働者の場合は，警察のた かり, 労働許可取得のための法的手続きに関する知識の不足, 日常生活でのゼノフォビアに直 面し, 移民としての脆弱な立場からくるリスクが高まっている。近代的な移民法や外国人労働 者管理を導入してもなお， ロシアにおいてこうした脆弱な移民の立場を守り，法的に就労し， 社会的リスクを軽減させる受入体制ができあがっていない。ソ連崩壊以後に移民研究を発展さ せてきたロシア研究に㧤いて，これまで十分に「外国人労働者問題」論が展開されてきたとは 言い難い。受入体制の充実を先送りにして, 人口減少と労働市場の供給不足への都合の良い補 充人員として受け入れてきた中央アジアからの外国人労働者たちの現状は, ロシアにおいて （定住を目的としない短期滞在型の）「外国人労働者問題」をひとつの研究テーマとして浮かび 上がらせるようになったと言える ${ }^{(12)}$ 。

\section{5 結 論}

ロシアは，ソ連崩壊以降，旧ソ連諸国に残された同胞の帰還問題，国境管理・出入国管理の 不備による中国人移民問題，そして 2000 年以降の高度成長と人口減少によって生み出された 労働力不足を補ら旧ソ連諸国からの移民労働の受入に対応するべく, 移民政策および外国人労 働者管理手法の確立に追われてきた。ロシア政府は移民問題を安全保障問題化し，ロシアのマ スコミも, そして一部の研究者もゼノフォビアを疜ってきた。移民労働なしには立ちゆかない とまで言われるロシア経済であっても，移民労働の受入体制は決して移民たちにやさしくはな い。欧露部では中央アジアからの外国人労働者を, ロシア極東地域では中国からの外国人労働 者をロシア各地方の経済維持に不可欠な構成要素として受入ながらも, ゼノフォビアや官吏の たかりが蔓延し，正規か正規でないか分からない仲介業者が横行し，外国人労働者が合法的に

(11) こうした研究の代表例としては, Тюрюканова (2009), Human Right Watch (2009), Marat (2009), 中村 (2007), 堀江・リャザンッェフ（2010）を参照されたい。

(12) ロシアを代表する人口論研究者リバコフスキーは, ロシアの移民問題の潮流を三段階に分け, ソ連崩 壊に伴う移民問題を第一段階, 1994 年以降の帰還移民たる同胞の移動の減少を第二段階, そして近年 の一時滞在型労働移民の問題を第三段階としている（Рыбаковский, 2009）。 
働ける環境作りが進まない。

1990 年代に先鋭化した中国人移民に対する脅威論が研究者の間では少なくとも冷静に観察 する潮流が中心になっていることは，歓迎すべきことである。すでに本稿でも引用したゲリブ ラスの著作名にもあるように，「ロシアの中国人の本当の姿」をロシアの移民研究に括いて丹 念に形成していくことは, 無用のゼノフォビアの曼延を防ぐために私たち研究者に課せられた 課題でもある。さらに，自らのビジネスをロシアで積極的に展開し中国とロシアを往来する短 期ビジネス移民として比較的豊かな中国人の活動が明らかになるにつれ， ロシア労働市場の底 辺で働く中央アジア諸国からの移民たちとの比較から移民間の階層化の問題が今後研究課題と

して浮かび上がってくる。

旧ソ連諸国, 特に中央アジア諸国からの外国人労働者がロシアの労働市場の底辺に構造的に 組み込まれている現状を本稿では明らかにした。柔軟な労働供給源としての中央アジア労働者 がロシアに颃いて直面する問題は多い。その問題を後回しにしながら，ユーラシア共通の労働 市場や共通の移民制度を構築しょうとしても，それはロシアを中心とした受入国のエゴを体現 したものとなる。ロシアに抢ける「外国人労働者問題」への真剣な取り組みが，ロシアの移民 大国への軌跡の延長線に課題として提示されている。

\section{参 考 文 献}

ウィッシュニック，エリザベス「移住と経済安全保障：ロシア極東の中国人労働移民」赤羽恒雄・アンナ・ ワシリエバ編『国境を越える人々: 北東アジアに括ける人口移動』国際書院，2006 年。

大津定美・Yu. アブデーエフ「北東アジア国際労働力移動とロシア極東」大津定美・韓福相・横田高明編 著『北東アジアに括ける経済連携の進展』日本評論社，2010 年。

ゲリブラス，ヴィリヤ「ロシアに拈ける中国人の同郷人組織とマイグレーション」大津定美編『北東アシ アに打ける国際労働力移動と地域経済開発』ミネルヴァ書房，2005 年。

ザイオンチコフスカヤ, ジャンナ「労働移民がつなぐロシアと中央アジア」, 堀江典生編著『現代中央ア ジア・ロシア移民論』ミネルヴァ書房，2010年。

デャトロフ, ビクトル「シベリア・極東地域に括けるステレオタイプと移民恐怖症」, 堀江典生編著『現 代中央アジア・ロシア移民論』ミネルヴァ書房，2010 年。

中村逸郎『虚栄の帝国 : 闇に消える「黒い」外国人たち』岩波書店，2007 年。

堀江典生「ロシアに拈ける移民政策の転換と人間安全保障 :ソフト・セキュリティ論の不安について」『環 日本海研究』第 12 号 (環日本海学会), 2006 年。

堀江典生「ロシアの職業と職務の変容: 遺制としての旧ソ連型職業分類」『比較経済研究』第 46 巻第 1 号 (比 較経済体制学会)，2009年。

堀江典生「北東アジアのなかの中ロ経済 : 反省と展望」大津定美・松野周治・堀汇典生編著『中口経済論 : 国境地域から見る北東アジアの新展開』ミネルヴァ書房, 2010 年。

堀江典生，七ルゲイ・リヤザンツェフ「モスクワの中央アジア移民 : 移民の語りから構築する中央アジア 移民像」堀江典生編著『現代中央アジア・ロシア移民論』ミネルヴァ書房，2010年。

湯浅 剛「ユーラシアの移民と安全保障 : 問題の位置づけとロシア，カザフスタンの現状」『防衛研究所 紀要』第 12 巻第 $2 \cdot 3$ 合併号, 2010 年。

Alexseev, Mikhail, Immigration Phobia and the Security Dilemma: Russia, Europe, and the United States, Cambridge Univ. Press. 2006.

Dyatlov, Viktor, "Anti-Immigrant Attitudes in the Socio-Political Life of a Siberian City: The Example of Irkutsk", Inner Asia, Vol. 2 No. 1, 2000, pp. 13-24.

Laruelle, Marlene, "Central Asian labor Migrants in Russia: The "Diasporization" of the Central Asian States?", China and Eurasia Forum Quartely, 5(3), 2007, pp. 101-119.

Human Right Watch, "Are you happy to cheat us": Exploitation of Migrant Construction Workers in Russia, Human Right Watch, 2009.

Marat, Erica, Labor Migration in Central Asia: Implications of the Global Economic Crisis, Central AsiaCaucasus Institute and the Silk Road Studies Program, 2009. 
Безруков, И.С. и Е.В. Горбенкова, Переспективы использавания азиатской рабочей силь в экономике Дальнего Востока России, Влвдивлсток: ВГУЭС, 2006.

Дацышен, В.Г., “Проблемыкитайской миграции в Сибири на современном этопе развития России”, Междкнародные иследования: общество. политика. экономика, Институт социальнополитических иследаваний (Казахстан), № 1(1), 2009, стр. 128-139.

Гельбрас, В.Г., Китайская реальность России, М., 2001.

Гельбрас, В.Г., Россия в условиях глобальной китайской миграции, М., 2004.

Гребенюк, А.А., "Реализация государственной программы по оказанию содействия добровольному переселению соотественников в Россию: Первые результаты”, ред., С.В.рязанцев и Р.В. Маньшин, Демографические перспективы России, М.: Academia, 2008, стр. 36-40.

Гришанова, А.Г., “Иммигранты из КНР и КНДР в Россию”, Народнаселение, № 3(45), 2009, стр. 64-74.

Ивахнюк, И.В., Евразийская миграционная система: Теория и политика, Москва: МАКС пресс, 2008.

Ивахнюк, И.В., “Как преодолеть страх чужего”, Миграция XX век, № 1, 2010, стр. 26-29.

Кириллова, Е.К., “Трудовая миграция как средство адаптации вынужденных переселенцев из стран СНГ в России”, ред. Ж.А. Зайончковская, Трудовая миграиия в СНГ: соииальнье и экономические эффекты, Москва: Центр изчения проблем вынужденной миграции в СНГ, 2003, стр. 197210.

Ларин, А.Г., Китайские Мигранты в России, М.:Восточная книга, 2009.

Ларин, В.Л., Китай и Дальний Восток России в первой половине 90-х: проблемь регионального взаимодействия, Владивосток: Дальнаука, 1998.

Ларин, В.Л., В тени проснувшегося дрпкона: Российско-китайские отношения на рубеже $X X-X X I$ веков, Владивосток: Дальнаука, 2006.

МОТ (Международная организация труда), Анализ подходов к проблеме оценки потребностей 8 трудящихся-мигрантах и планирование миграции рабочей силь: российская Федерация и международный опьыт, Москва: МБТ, 2009.

Росстат (Федеральная служба государственной статистики), Труд и занятость в России, 2009.

Мотрич, Е.Л., Население Дальнего Востока России, ДВО РАН, 2006.

Рыбаковский, А.А., “Миграционные процессы и формирование миграционной политики России”, Народонаселение, № 4(46), 2009, стр. 4-12.

Рязанцев, С.В., Трудовая миграция в странах СНГ и Балтии: тендениии, последствия, регулирование, Москва: Формура права, 2007.

Рязанцев, С., и Х. Ян, Китайская миграция в Россию, Тендениии, последствия и подходьл к регулированию, М., 2010.

Тюрюканова, Е.В., “Трудовые мигранты в Москве: «втрое» общество”, под. ред. Ж.А. Зайончковская, Иммигранты в Москве, Москва: «Три квадрата», 2009.

Тюрюканова, Е.В., “Дещевые работники дорогого стоят”, Миграция XX век, № 1, 2010, стр. 43-44.

（付記）本稿は，平成 21-23 年度科学研究費補助金基盤研究（B）「ロシア極東再開発の潜在力 と限界：中ロ経済相互依存関係から見る諸課題」（課題番号：21402019）拈よび平成 22 年度特別経費事業「東アジアに拈ける『共生』学創成の学際的融合研究」(富山大学) の研究成果の一部である。 